\title{
Low Carbon City Development in China in the Context of New Type of Urbanization
}

\author{
Md. Nazirul Islam Sarker ${ }^{*}$, Md. Altab Hossin'2, Yin Xiao Hua ${ }^{3}$, Jhensanam Anusara ${ }^{4}$, \\ Srichiangrai Warunyu ${ }^{4}$, Bouasone Chanthamith ${ }^{1}$, Md. Kamruzzaman Sarkar5, \\ Nitin Kumar', Sita Shah" \\ ${ }^{1}$ School of Public Administration, Sichuan University, Chengdu, China \\ ${ }^{2}$ Department of Management Science and Engineering, University of Electronic Science and Technology of China, Chengdu, China \\ ${ }^{3}$ School of Automation Engineering, University of Electronic Science and Technology of China, Chengdu, China \\ ${ }^{4}$ Business School, Sichuan University, Chengdu, China \\ ${ }^{5}$ Department of Zoology, National University, Gazipur, Bangladesh \\ Email: *sarker.scu@yahoo.com
}

How to cite this paper: Sarker, Md.N.I., Hossin, Md.A., Hua, Y.X., Anusara, J., Warunyu, S., Chanthamith, B., Sarkar, Md.K., Kumar, N. and Shah, S. (2018) Low Carbon City Development in China in the Context of New Type of Urbanization. Low Carbon Economy, 9, 45-61.

https://doi.org/10.4236/lce.2018.91004

Received: January 25, 2018

Accepted: March 25, 2018

Published: March 28, 2018

Copyright $\odot 2018$ by authors and Scientific Research Publishing Inc. This work is licensed under the Creative Commons Attribution International License (CC BY 4.0).

http://creativecommons.org/licenses/by/4.0/

\begin{abstract}
Urbanization is an important part of economic development in China which directly related to industrial development. Industrial development is based on energy production, consumption, and trade. A new type of urbanization with low carbon city development is an urgent matter in the researcher community for developing an appropriate strategy, policy, technology, and action. The aim of this study is to explore the status and assess the strategy and policy of low carbon city development in the context of urbanization. It also finds out the effects of new type of urbanization on low carbon city development by finding out constraints and providing recommendations. An extensive literature review with meta-analysis has been done considering various indicators of low carbon city development. This study reveals that most of the large cities are already under the pilot projects of low carbon city development. It also finds out some major indicators of low carbon city like economic growth, energy using pattern, social and lifestyle factor, carbon and environment, urban mobilization, solid waste management, and water management in the context of urbanization. Rapid urbanization requires more building construction and energy which emits more GHG. It suggests that an assessment index system should be introduced by the government to control, monitor and motivate people to use low carbon technology. It further suggests that rules and regulations, awareness building, locality-based technology and practices, and participation of all stakeholders in policy making should be maintained by the government for sustainable low carbon city development in China.
\end{abstract}




\section{Keywords}

Low Carbon City, Urbanization, Sustainable Development, GHG Emission

\section{Introduction}

Urbanization is an important part of social and economic development in China. The process of urbanization in China is faster than other countries. The urban people of China will be 500 million by 2050 [1]. There are so many challenges in China due to the fastest urbanization which characterized by suffering world's pre- and post-urbanization like air pollution, water pollution, expansion of urban sprawl, traffic congestion and high carbon emission. People-centered and the eco-friendly urban environment is necessary to lead a comfortable urban life in China. Rapid urbanization requires high energy consumption for high production in the industry as well as people's daily life [2]. By 2030, the carbon emission will be 8 tonnes per capita in China due to carbon using pattern in the industry and urban life [3]. China's per capita energy consumption is more than global average but China can reduce its energy consumption by adopting low carbon technology and strategic pattern of energy consumption which helps to reduce $20 \%$ GHG emission by 2030 [4].

The term and concept of "low carbon city" were introduced in 2008 in China by a non-government organization, World Wildlife Fund (WWF) [5] [6]. The carbon emission bears $88 \%$ aluminum, $80 \%$ energy, $86 \%$ iron, $75 \%$ cement and $92 \%$ copper [4]. Some strategic plannings like the restructuring of industry, transport efficiency, lifestyle change, more efficiency in building and electricity, industrial endues and developing energy sector should be adopted by the Chinese authority to reduce carbon emission [7]. Chinese people prefer urban area for their living and it is one of the causes of social transformation which challenges low carbon practices in China. According to City Metabolize statistics, urban population consumes and emits Green House Gas (GHG) about 46\% of the total population which deserves special attention for research and practice for low carbon city development [1]. Rapid urbanization and industrialization in China require promoting low city development and tackling rapid rural-urban migration, limited resources, and large population. It also causes some negative effects of air pollution, water pollution, increasing noise, traffic congestion, solid and liquid waste. GHG emission rate in city areas in China is larger than rural areas due to more fossil fuel use and its growing demand. Though China initiated low carbon city development project in 79 cities it faces challenges due to the traditional pattern of carbon practices, institutional rigidness and less finance [8]. The negative effects of urbanization may cause a serious problem for human settlement [6]. The article tries to fill the gap in the literature by exploring the answer to the questions like i) what is the extent of low carbon city development in China? ii) what strategies and policies are necessary for low carbon 
city development in the context of urbanization? iii) what are the barriers to low carbon city development? These questions lead the research team to determine the specific objectives like i) to explore the status of low carbon city development in China; ii) to assess the strategy and policies of low carbon city development in the context of urbanization; iii) to explore the effects of new type of urbanization of China on low carbon city development; iv) to find out the constraints of low carbon city development in the perspective of new type of urbanization in China; v) to suggest some measures to overcome the constraints of low carbon city development based on findings.

This article depicts research methodology section after introduction including data collection and treatment and data analysis method. The third and fourth section describes a review of related literature and status of low carbon city development in China respectively. The fifth section describes the policy implications for facilitating the low carbon city development in the perspective of the new type of urbanization. The final section concludes the article.

\section{Methodology}

\subsection{Research Design}

The study mainly focuses on concept, indicators and implementation challenges and opportunities of low carbon city development in the perspective of fastest urbanization in China. A conceptual model is developed for low carbon city development in China through extensive literature review [9]. The research is descriptive in nature based on some indicators of low carbon city development (Figure 1).

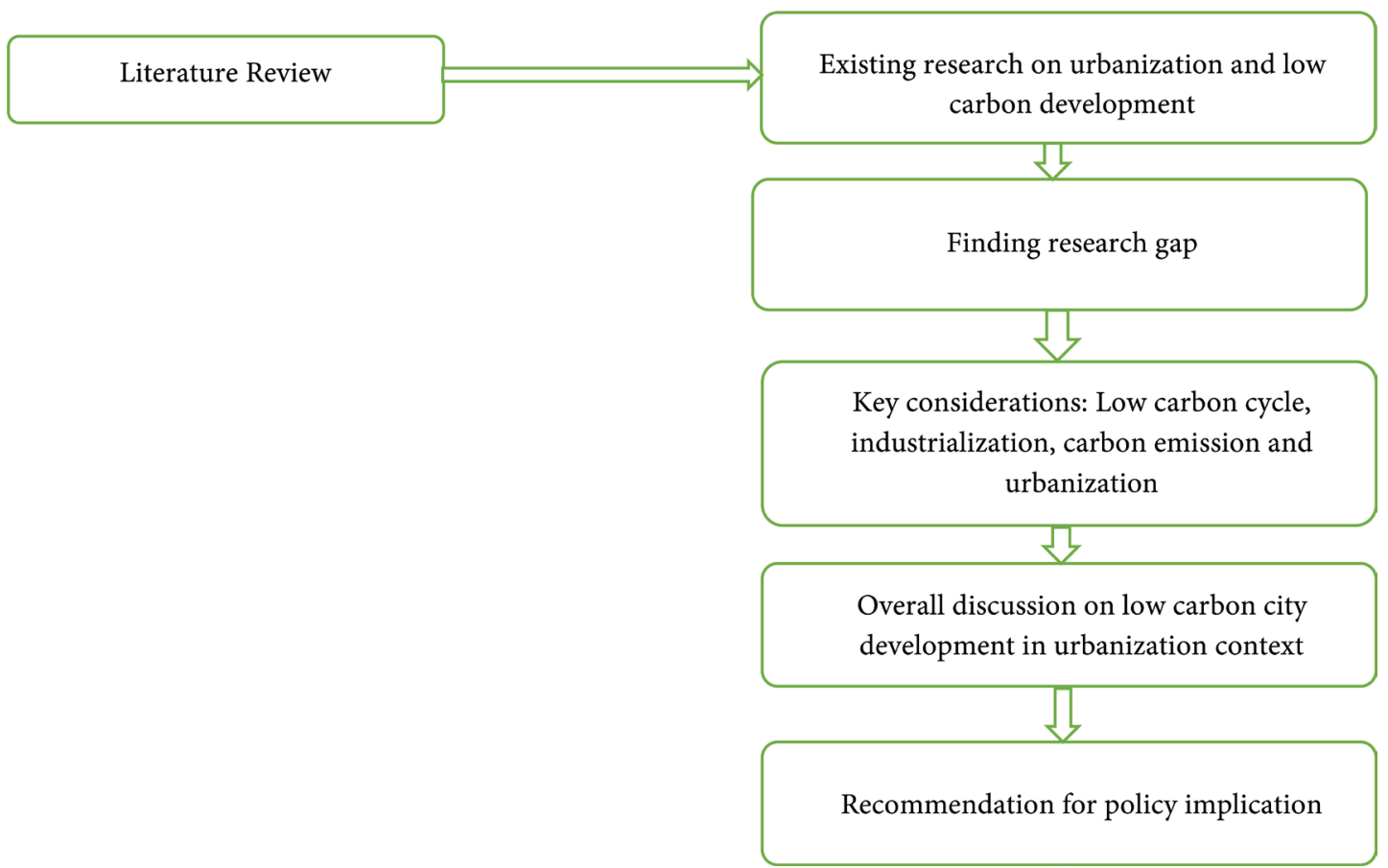

Figure 1. Research design for low carbon city development in China. 


\subsection{Sources of Data}

This study has been extensively used secondary sources related to the concept, indicators and practices of low carbon city development, adoption of modern eco-friendly technologies, low carbon governance, climate change effects, air and water pollution and the adverse effect of the unplanned future economy. Some developed and developing countries are in the stage of rapid urbanization and low carbon city development is a prior issue to them. Though this study has been confined to China but it is applicable for other developed and developing countries.

\subsection{Search Strategy}

This study has been extensively searched some renowned databases like Google scholar, a web of science, science direct, Springer link, researchgate website using important keywords like "low carbon city, technology, urbanization, eco-friendly city, climate change, and China for securing reliable information" [10]. The data collection and analysis for this study has been done from November to December 2017. According to Liu \& Qin, a literature review is a significant part of the development of a field [1]. It offers an opportunity to synthesize and reflect on previous research, and thus providing secure grounding for the advancement of knowledge [9]. Finally, 75 journal articles and books are selected for qualitative content analysis for this study. The supporting data has been taken from government statistics and other sources on the internet with due verification (Figure 2).

\subsection{Data Analysis}

Data is analyzed from different perspectives of low carbon practices, technologies,

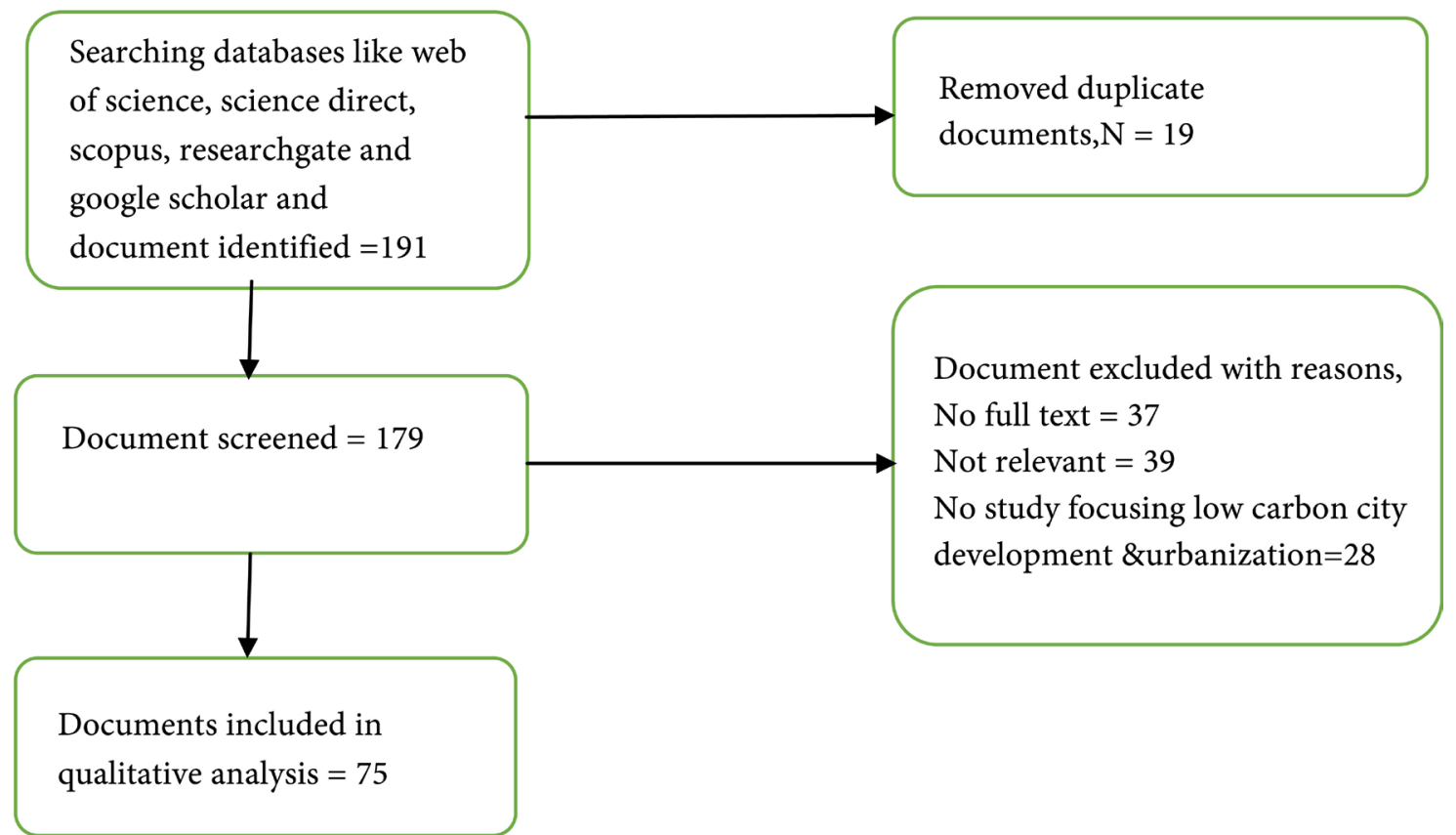

Figure 2. Flow diagram of study selection. 
indicators, challenges and opportunities of technology adoption, climate change effect and environmental governance.

\section{Review of Related Work}

The rate urbanization in China is increasing rapidly as the urbanization rate was about $36 \%$ in 2000 but increased to about 53\% in 2012 [11]. The rapid and new type of urbanization faces an acute pressure for infrastructure, urban resources, land, real estate, pollution and economic development due to making new cities adjacent to old cities, urban expansion, and migration [12]. About $18 \%$ of the total population is living in 35 largest cities in China [13]. The percentages of urbanized people are increasing due to the fastest rate of a new type of urbanization. The more people require more energy, more building construction and more resources which lead to more Greenhouse Gas Emission (GHG), air and water pollution. Global warming and climate change are the effects of Greenhouse Gas Emission (GHG). About 40\% - 78\% GHG emissions are originated from cities due to the cause of fastest urbanization [14]. The rate of GHG emission is increasing gradually with increasing urbanization. Traditional urbanization follows energy-intensive development patterns which require increased energy consumption along with rising living standards [15]. China is undergoing fastest urbanization on an unbalanced scale as a largest developing country.

The scarce natural resources, overpopulation pressure and limited climate and urban finance, make the cities of China vulnerable to climate change impacts. Some cities of the northern and western part of China have already faced some climate change impacts like a sandstorm, drought, and smog while the cities of eastern and southern part of China are experiencing rainstorm and frequent flood [12]. According to Liu and Deng [16], cities of northern China is experiencing decrease at $2 \%$ to $10 \%$ while flood-prone cities of southern China faces more than $20 \%$ average annual precipitation. Some cities of China viz Shanghai, Guangzhou already faces some climate change effects like rainstorms in every summer. Since urbanization creates so much pressure on energy, environment and carbon emission, so a decarburization strategy should be taken by the policy makers irrespective of regional and national level for saving the citizen and developing low carbon city [12].

Low-carbon city program was initiated in China in 2008 and subsequently, the low-carbon city experimental project was launched in eight cities viz Chongqing, Xiamen, Nanchang, Tianjin, Guiyang, Shenzhen, Baoding and Hangzhou in 2010 [13]. Low carbon pilot project included another 29 provinces and cities in 2012 which covers $57 \%$ of total GDP, $42 \%$ of total population and $56 \%$ of energy-related $\mathrm{CO}_{2}$ emissions [12]. The goals of the new development strategy of China are sustainable urbanization, ecological civilization and scientific development which can be achieved by low-carbon city development through integration of low-carbon society and low-carbon economy [6] [17]. So, low carbon city development is not only for better lifestyle but also for the better economic development of the city (Table 1 ). 
Table 1. Major research on low carbon economy.

\begin{tabular}{|c|c|c|}
\hline Researcher \& duration & Summary of finding & Journal or source \\
\hline Zhang et al., 2017 [18] & $\begin{array}{l}\text { China's cities also must ensure sustainable development in line with national } \\
\text { efforts to transition to a less carbon-intensive economy. }\end{array}$ & $\begin{array}{l}\text { Sustainable Low-Carbon City } \\
\text { Development in China }\end{array}$ \\
\hline Cai et al., 2017 [19] & The spirit of a "Low Carbon City" is not consistently understood by the society. & Journal of Cleaner Production \\
\hline Chen et al., 2017 [20] & $\begin{array}{l}\text { Data on greenhouse gas (GHG) emission are vital for the reduction of carbon } \\
\text { emissions and the development of low-carbon strategies. }\end{array}$ & $\begin{array}{l}\text { Resources, Conservation and } \\
\text { Recycling }\end{array}$ \\
\hline $\begin{array}{l}\text { Adenle, Manning, \& } \\
\text { Arbiol, (2017) [21] }\end{array}$ & $\begin{array}{l}\text { Developing countries participation is necessary to encourage low-carbon } \\
\text { development pathways. }\end{array}$ & World Development \\
\hline $\begin{array}{l}\text { Chen et al., (2017) } \\
{[20]}\end{array}$ & $\begin{array}{l}\text { China has a target to reduce } 65 \text { percent carbon intensity by } 2030 \text { through the } \\
\text { adoption of modern energy technology. }\end{array}$ & $\begin{array}{l}\text { Resources, Conservation and } \\
\text { Recycling }\end{array}$ \\
\hline $\begin{array}{l}\text { Zhang, Li, \& Zhou, } \\
\text { (2017) [18] }\end{array}$ & $\begin{array}{l}\text { Developing low-carbon buildings has become a communal trend in the world in } \\
\text { the perspective of energy consumption and carbon emissions. }\end{array}$ & Journal of Cleaner Production \\
\hline Liu et al., (2017) [22] & $\begin{array}{l}\text { Target Responsibility System (TRS) is a vital key to the reduction of } \mathrm{CO}_{2} \text { per unit } \\
\text { GDP. }\end{array}$ & Journal of Cleaner Production \\
\hline Lo, K [23] [24] & $\begin{array}{l}\text { Policies related to low-carbon cannot be implemented properly due to the poor } \\
\text { scoring system, weak targets, energy intensity, and lack of reliable local energy } \\
\text { statistics. }\end{array}$ & $\begin{array}{l}\text { Environmental Science \& } \\
\text { Policy }\end{array}$ \\
\hline Han et al., (2018) [25] & $\begin{array}{l}\text { The local and neighboring cities in China emit more carbon due to specialization } \\
\text { and diversification industry. }\end{array}$ & Journal of Cleaner Production \\
\hline Yang et al. (2018) [26] & The intensive energy consumption in urban sectors is infuriating global warming. & Journal of Cleaner Production \\
\hline $\begin{array}{l}\text { Fu \& Zhang, (2017) } \\
{[15]}\end{array}$ & $\begin{array}{l}\text { The eco-new towns are more concerned with the promotion of a sustainable way } \\
\text { of life in GHG emission context. }\end{array}$ & Habitat International \\
\hline $\begin{array}{l}\text { Wang, Engels, \& } \\
\text { Wang, (2017) [27] }\end{array}$ & $\begin{array}{l}\text { Strong structural changes in existing development pattern are essential for short } \\
\text { and long-term low carbon development. }\end{array}$ & $\begin{array}{l}\text { Renewable \& Sustainable } \\
\text { Energy Reviews }\end{array}$ \\
\hline Guo et al., (2017) [28] & $\begin{array}{l}\text { The approach of carbon balance analysis can help for monitoring policy } \\
\text { effectiveness for sustainable carbon economy. }\end{array}$ & $\begin{array}{l}\text { Resources, Conservation and } \\
\text { Recycling }\end{array}$ \\
\hline $\begin{array}{l}\text { X. Ma, Wang, \& } \\
\text { Wang, } 2017[29]\end{array}$ & $\begin{array}{l}\text { China will have difficulty in realizing its carbon reduction target by } 2020 \text { if the } \\
\text { present rate of GHG emission exists in the thermal power industry. }\end{array}$ & $\begin{array}{l}\text { Renewable and Sustainable } \\
\text { Energy Reviews }\end{array}$ \\
\hline $\begin{array}{l}\text { Cheshmehzangi, Xie, } \\
\text { \& Tan-Mullins, } 2017 \\
{[30]}\end{array}$ & $\begin{array}{l}\text { Participation of Chinese and international partners for low carbon occurs in the } \\
\text { ways of the type of involvement, the level and timeframe of involvement and the } \\
\text { level of Influence on the project. }\end{array}$ & Cities \\
\hline Dong et al., 2013 [13] & $\begin{array}{l}\text { Low-carbon city strategy in China launched for responding global climate change } \\
\text { and sustainable urbanization. }\end{array}$ & Energy Policy \\
\hline $\begin{array}{l}\text { Fu, and Zhang, (2017) } \\
\text { [15] }\end{array}$ & $\begin{array}{l}\text { A sustainable city, eco-cities, and low-carbon cities concepts have received a } \\
\text { national endorsement in China. }\end{array}$ & Habitat International \\
\hline Guo et al., 2017 [28] & $\begin{array}{l}\text { Urbanization advances great challenges for global sustainability with the increasing } \\
\text { carbon constraints in the context of carbon emission and climate change. }\end{array}$ & $\begin{array}{l}\text { Resources, Conservation and } \\
\text { Recycling }\end{array}$ \\
\hline Kedia, $2016[4]$ & $\begin{array}{l}\text { Domestic policies and international partnerships are successfully engaged for low } \\
\text { carbon city development in China. }\end{array}$ & $\begin{array}{l}\text { Advances in Climate Change } \\
\text { Research }\end{array}$ \\
\hline $\mathrm{He}, 2016[31]$ & China is being implemented green and low-carbon development strategy. & $\begin{array}{l}\text { Advances in Climate Change } \\
\text { Research }\end{array}$ \\
\hline
\end{tabular}




\section{Continued}

Lv \& Qin, 2016 [32]

Yuan, 2016 [33]

Liang et al., 2014 [34]

Liu, and Qin, 2016 [1]

Lo, 2014 [24]

Su et al., 2012 [5]

Su et al., 2016 [35]

Tan et al., 2017 [7]

Yang et al., 2017 [26]

Yang \& Li, 2013 [36]

$\mathrm{Yu}, 2014[2]$

Zhang et al., 2017 [18]

Zhou et al., 2018 [37]

Zhou et al., 2015 [38]
Low-carbon technology mainly includes carbon reduction technology,

carbon-free technology, carbon removal technology, carbon management technology, resource saving and recycling technology.

Carbon finance not only provides a number of means for the development of low carbon economy but also offers a new development space for the innovation of the financial system.

The low carbon development roadmap is extremely important for China's lack of energy resources, serious environmental pollution, and huge greenhouse gas (GHG) emission.

China has largely formed a multilayer and multi-actor policy-making process for developing low-carbon cities.

China has already disseminated a wide variety of low-carbon initiatives to reduce energy consumption and carbon emissions in the cities.

Many cities in China have been dedicated to the expansion of low-carbon city construction nowadays.

Low-carbon city in China is necessary for reducing huge cost of climate change particularly for city's greenhouse gas emissions.

Many cities are pursuing the low-carbon practices to reduce $\mathrm{CO}_{2}$ and other environmental emissions.

The intensive energy consumption in urban sectors is stimulating global warming, which prompts thinking on energy-carbon nexus and low-carbon city actions.

The development of low carbon city is required to cope with global climate change and sustainable development of economic society.

The application of low carbon eco-city strategy should be contributed to the solution in addressing upcoming challenges.

The current pattern of low-carbon buildings in China's urban area is still dissatisfactory.

China is in a period of rapid urbanization, which has led to increased demands for energy. Approximately $85 \%$ of China's $\mathrm{CO}_{2}$ emissions are related to urban energy consumption.

China is pursuing the development of low-carbon eco-cities to limit carbon dioxide and other greenhouse gases emissions.
Low Carbon Economy

Low Carbon Economy

Energy Procedia

Cities

Habitat International

Procedia Environmental

Sciences

Energy Procedia

Applied Energy

Journal of Cleaner Production

Sustainable Cities and Society

Habitat International

Journal of Cleaner Production

Journal of Cleaner Production

Ecological Indicators

The major strategy of sustainable urbanization requires a low carbon city development planning, policy, and development pattern since Chinese cities are facing various constraints in implementing a new type of urbanization.

\section{Current Status of Low Carbon City Development in China}

Sustainable urbanization is a new challenge for Chinese cities due to the continuous migration of people from the countryside to urban areas, environmental pollution, and energy consumption. A continuous and new approach is necessary for sustainable low carbon city development in order to cope with the con- 
tinuous challenges and pressures of social and environmental factors.

\subsection{Concept of Low Carbon City}

A low carbon city is an approach to the transformation from industrial civilization to ecological civilization which covers the challenges of urbanization considering low carbon practices. Energy saving and low carbon emission are the priority sector in the economic development process which faces the challenges driven by global politics, climate change, energy consumption \& crisis, and urbanization. In 2003, the British government first proposed low carbon economy through Energy White Paper entitled to "Our Energy Future: Creating a low carbon economy". A low carbon economy can be achieved through practicing low carbon city development. One of the major purposes of low carbon city is to reduce energy consumption and carbon emission i.e. low carbon energy is related to low carbon city development. Low carbon city is also an urban development model which stimulates the initiation and development of new type of urban economics for reducing energy consumption and carbon emission (Figure 3).

The challenges of urbanization in the process of city development are meeting up with the similar concepts of low carbon city, eco-city, and low carbon eco-city development in China. This low carbon city concept was decided by the Fourth Plenary Session of the $16^{\text {th }}$ Chinese Communist Party Central Committee

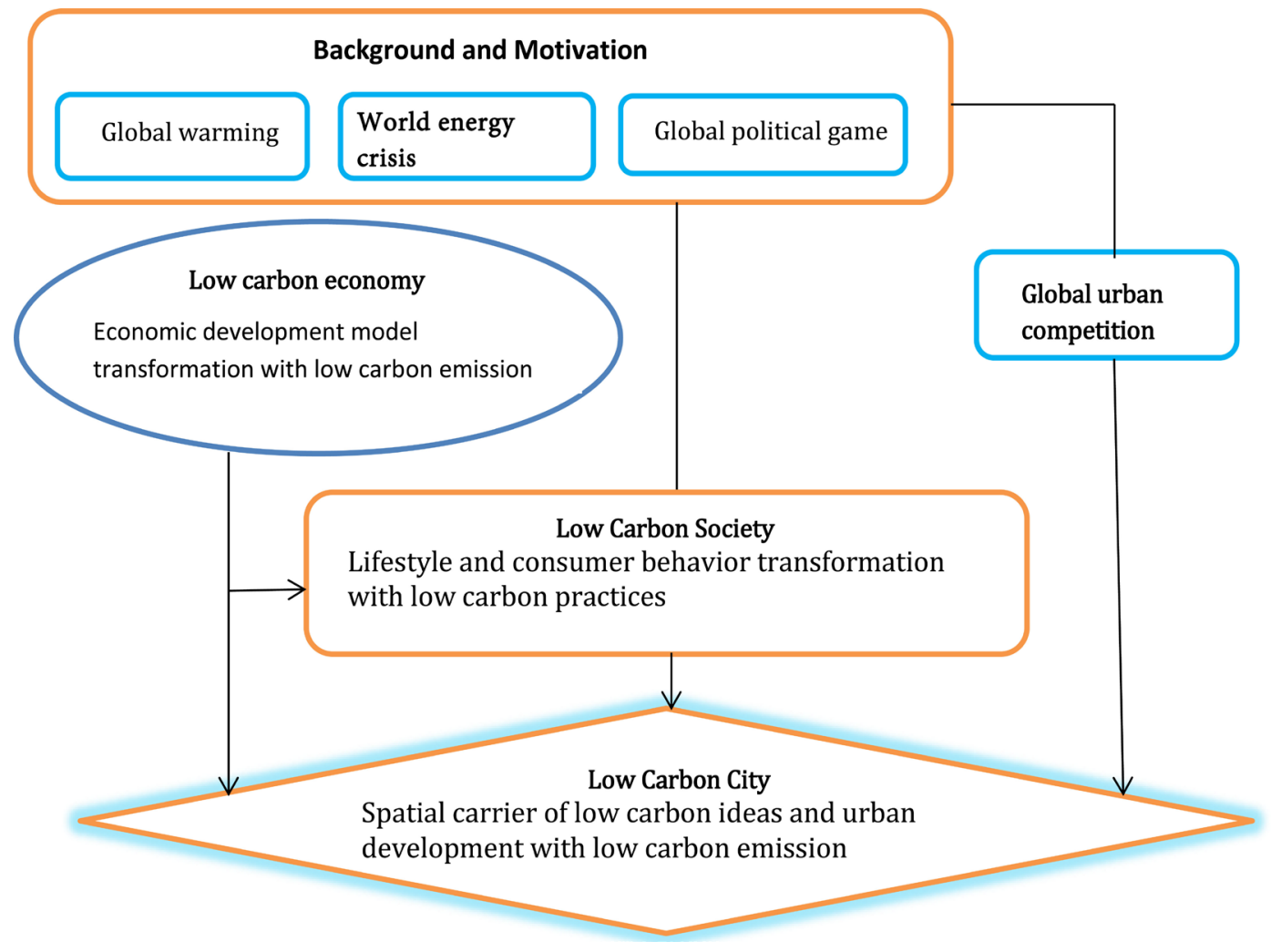

Source: Adapted from [39].

Figure 3. The origin of low carbon city. 
for developing eco-friendly, energy saving and self-dependent model. The major purpose of this model is to reduce poverty, developing an eco-friendly environment and promoting renewable energy sources. This plan was further strengthened through the $18^{\text {th }}$ National Congress of the Communist Party of China [40]. The concept also explained in last few years as sustainable or eco-city development. Some other scholars described the eco-city from various perspectives. According to Feng et al. [41], eco-city usually saves energy, water, and other natural resources by reducing pollution and waste. As a result, an eco-city is an approach to saves fossil resources and provides an attractive place for living and working. According to Zhang [42], an eco-city is a city which includes harmonious human development, synchronization of ecological, economic and social factors, economic and environmental components. Yu [2] mentioned that eco-city is a process which stimulates environmental, economic and social development through transforming traditional production patterns and improving lifestyles (Table 2).

\subsection{Introducing Low Carbon Policy}

The National Development and Reform Commission (NDRC) selected 6 provinces and 36 cities for low carbon cities pilot projects for reducing carbon emission in the industry and promoting eco-friendly development as a responsible body of government [2]. The Ministry of Environmental Protection (MEP) of China has also played a vital role in reducing GHG emission and low carbon city development. The MEP also conducting other related works like controlling polluters, monitoring, supervising and licensing industrial bodies, reviewing the

Table 2. Similar concepts to Low carbon city.

\begin{tabular}{|c|c|c|c|}
\hline Terms & Definition & Researcher & Examples \\
\hline $\begin{array}{l}\text { Sustainable } \\
\text { City }\end{array}$ & $\begin{array}{l}\text { It stimulates social equity, economic productivity, and environmental } \\
\text { quality to meets the needs of the present without compromising the } \\
\text { ability of future generations to meet their own needs. }\end{array}$ & $\begin{array}{l}\text { Riviere et al.,2013 [43] } \\
\text { Liu et al., } 2016 \text { [44] }\end{array}$ & 1) Malmö, Sweden \\
\hline Eco-city & $\begin{array}{l}\text { A city where human beings can exist in harmony with nature } \\
\text { therefore greatly reducing ecological footprint. } \\
\text { A city that creates economic opportunities for their citizens in an } \\
\text { inclusive, sustainable, and resource-efficient way, while also } \\
\text { protecting and nurturing the local ecology and global public goods, } \\
\text { such as the environment, for future generations. }\end{array}$ & $\begin{array}{l}\text { Suzuki et al. } 2010[45] \\
\text { World Bank, } 2015[46]\end{array}$ & $\begin{array}{l}\text { 1) Sino-Singapore Tianjin } \\
\text { Eco-city, China } \\
\text { 2) City of Copenhagen, } \\
\text { Denmark } \\
\text { 3) Stockholm, Sweden } \\
\text { 4) Yokohama, Japan }\end{array}$ \\
\hline Smart city & $\begin{array}{l}\text { The safe, secure, environmental and efficient urban center of the } \\
\text { future with advanced information and communication technologies } \\
\text { (ICT) to stimulate sustainable development in the economic growth } \\
\text { and a high quality of life }\end{array}$ & $\begin{array}{l}\text { UNESCAP, } 2012[47] \\
\text { Sarker, } 2017[48]\end{array}$ & $\begin{array}{l}\text { 1) Barcelona, Spain } \\
\text { 2) Luxembourg }\end{array}$ \\
\hline $\begin{array}{l}\text { Carbon } \\
\text { neutral city }\end{array}$ & $\begin{array}{l}\text { Similar to "LCC" except defined more strictly as a city which has } \\
\text { zero carbon emissions. }\end{array}$ & $\begin{array}{l}\text { Adelaide City Council, } \\
2015 \text { [49] }\end{array}$ & 1) Melbourne, Australia \\
\hline $\begin{array}{l}\text { Zero carbon } \\
\text { city }\end{array}$ & $\begin{array}{l}\text { More specifically to a city which produces no GHG and is run } \\
\text { exclusively on energy from renewable sources }\end{array}$ & $\begin{array}{l}\text { Urban World, } 2009[50] \\
\text { Hannallah \& } \\
\text { Faragallah, } 2009[50]\end{array}$ & $\begin{array}{l}\text { 1) Masdar City, United } \\
\text { Arab Emirates } \\
\text { 2) Dongtan, China }\end{array}$ \\
\hline
\end{tabular}


progress of pollutants through local government [2]. In 2012, the MEP provided an award to 38 National eco-cities (or counties) and 1559 National eco-towns for best practices in environmental protection [12].

Urban and rural human settlement sector is under the Ministry of Housing and Urban-Rural Development (MoHURD) of China which assess the best practices of urban settlement by some standard indicators and contribute to low carbon city development in the new type of urbanization [51] (Figure 4) (Table 3).

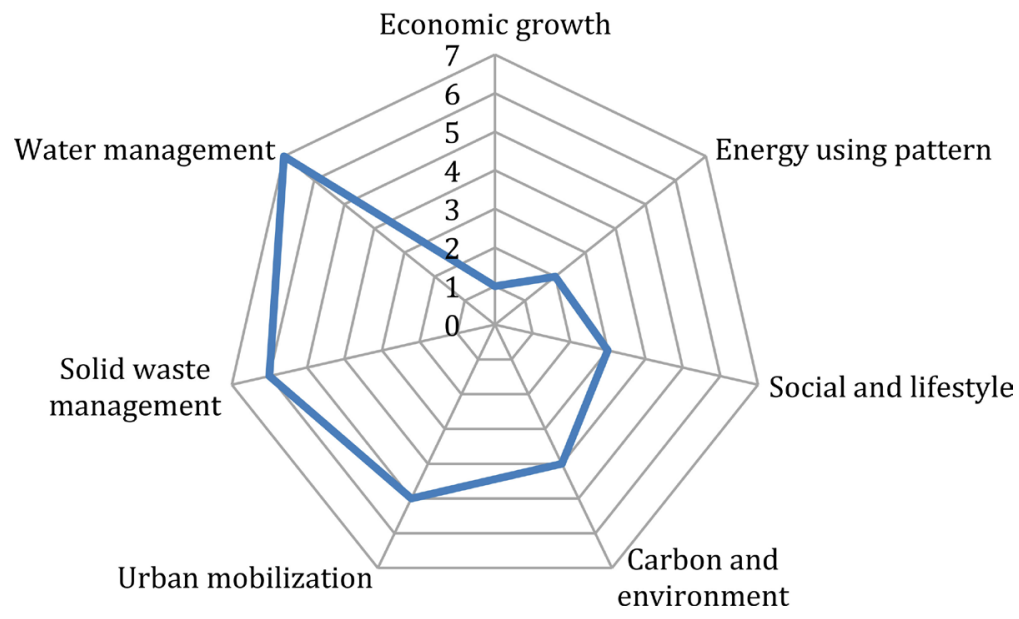

Figure 4. Dimensions of low carbon city (LCC) development.

Table 3. Dimensions of low carbon city (LCC) development.

\begin{tabular}{|c|c|c|}
\hline Category & Indicator & Researcher \\
\hline Economic growth & $\begin{array}{l}\text { - } \quad \text { Per capita GDP } \\
\text { - Proportion of tertiary industry to GDP } \\
\text { - } \text { Carbon productivity }\end{array}$ & $\begin{array}{l}\text { World Bank, } 2015 \text { [46] } \\
\text { Cheng et al., } 2012 \text { [39] EIU, } 2012 \text { [52] } \\
\text { Suzuki et al., } 2010 \text { [45] }\end{array}$ \\
\hline Energy using pattern & $\begin{array}{l}\text { - Proportion of renewable energy } \\
\text { - Energy intensity }\end{array}$ & $\begin{array}{l}\text { EIU, 2012 [52] } \\
\text { Tan et al., } 2017 \text { [52] [7] }\end{array}$ \\
\hline Social and lifestyle & $\begin{array}{l}\text { - Proportion of public green space } \\
\text { - Population density Population } / \mathrm{km}^{2}\end{array}$ & $\begin{array}{l}\text { Tan et al., } 2017 \text { [7] UN-Habitat, } 2011 \\
\text { [14] }\end{array}$ \\
\hline $\begin{array}{l}\text { Carbon and } \\
\text { environment }\end{array}$ & $\begin{array}{l}\text { - } \mathrm{CO}_{2} \text { emission/capita ton/person Nitrogen dioxide emission/capita } \\
\mathrm{lg} / \mathrm{m}^{3} \\
\text { - Daily sulfur dioxide levels } \mathrm{lg} / \mathrm{m}^{3} \\
\text { - daily suspended particular matter levels } \mathrm{lg} / \mathrm{m}^{3}\end{array}$ & Zhou et al., 2015 [38] Garcia, 2017 [53] \\
\hline Urban mobilization & $\begin{array}{l}\text { - Public buses per capita Public buses/million persons } \\
\text { - Rail length per capita } \mathrm{km} / \mathrm{million} \text { persons } \\
\text { - Cars per capita Private cars/persons }\end{array}$ & $\begin{array}{l}\text { EIU, } 2012[52] \\
\text { WHO, } 2014[54]\end{array}$ \\
\hline $\begin{array}{l}\text { Solid waste manage- } \\
\text { ment }\end{array}$ & $\begin{array}{l}\text { - Solid waste generation per Capita } \mathrm{kg} / \mathrm{capita} / \mathrm{day} \\
\text { - Share of waste collected and adequately disposed } \\
\text { - Share of waste energy } \\
\text { - Share of material recycling }\end{array}$ & $\begin{array}{l}\text { Hoornweg \& Bhada, 2012 [55] } \\
\text { Shen et al., } 2018 \text { [56] } \\
\text { Baeumler et al. } 2012 \text { [57] }\end{array}$ \\
\hline Water management & $\begin{array}{l}\text { - Share of wastewater treated } \\
\text { - Water consumption intensity L/capita/day }\end{array}$ & $\begin{array}{l}\text { Zhou et al., } 2015 \text { [38] } \\
\text { Suzuki et al., } 2010 \text { [45] }\end{array}$ \\
\hline
\end{tabular}




\subsection{Manufacturing Sector and Carbon Emission}

Rapid industrialization in China stimulates manufacturing industries, especially iron and steel, cement and chemical industry. Most of them are established in the cities which are located in the newly established industrial parks [58]. It provides a great opportunity for Chinese cities to encourage industrial symbiosis as well as low-carbon strategy, demanding a systematical evaluation so that quantitative evidence can be provided for future policymaking. However, comprehensive study focus on this topic remains challenging, due to model limitation and data unavailability.

\subsection{Transportation Sector and Carbon Emission}

Electricity production, industrial fuel use, and ground transportation are the major source of carbon emission in Chinese cities. The average rate of emission is higher than cities of other developed countries of the world [18]. This study analyzes the sources of carbon emission in various Chinese cities and finds three major GHG contributing sectors like energy consumption, industrial system, and transportation. Some major sectors are considered by some researcher with transportation like energy supply and consumption, construction of the building, agriculture, industry, and planning of new urban areas [59]. Some others mentioned that economic and policy instruments are the major effective keys for low-carbon development [1]. Major instruments are labeling and certification of energy, beginning inner carbon markets and inspiring energy pricing reforms [22] [13]. The main low carbon practices for city development are upgrading industrial structure, relocation of industry, energy savings, energy friendly technology, and transportation of low carbon [60] [61]. Establishing energy standard, urban planning, and public transportation are the major instruments for achieving goals of $\mathrm{CO}_{2}$ reduction which must be considered by the concerned authority [1] [62].

\subsection{Building Sector and Carbon Emission}

One of major GHG emission sector is building sector which covers $14.11 \%$ of total emission with other sectors like $41.36 \%$ by transport and communication sector and $10.41 \%$ education and recreation sector [12]. Most of the big cities are suffering from poor land use. The development of low-carbon cities has been encouraged worldwide because cities are key drivers of energy consumption and related carbon emissions [63]. Regulation and technological improvements will play an important role in mitigating GHG emissions in some Chinese cities. Carbon reductions require a transformation of the city's lifestyle, social and economic development pattern which includes clean energy policies to encourage change in its energy system [28]. Knowledge, expertise, science, and technology from foreign countries are considered to be a key component of developing low-carbon cities [19]. Some researchers have suggested that low carbon development of China's cities need to learn from and collaborate with successful 


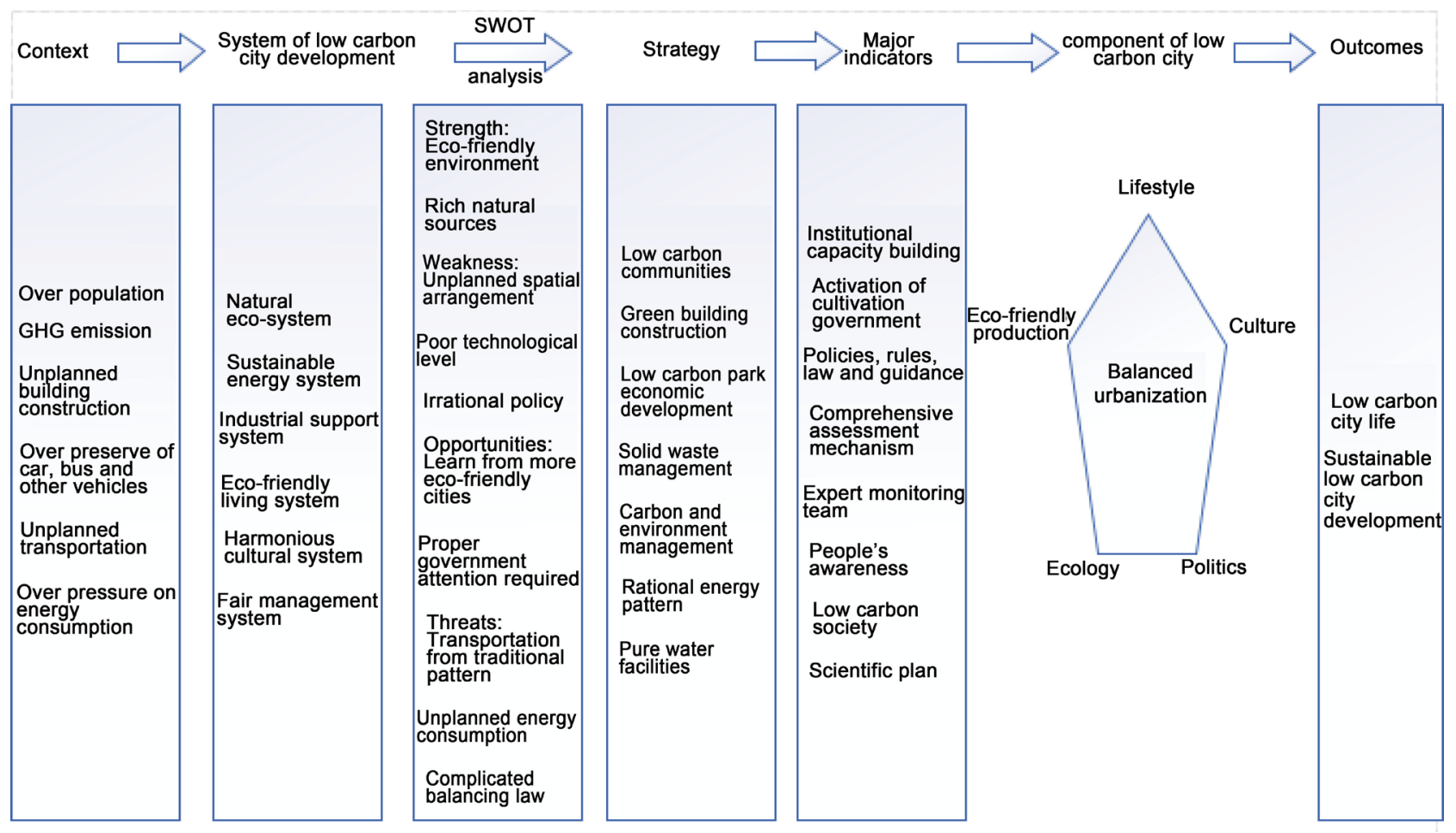

Figure 5. Conceptual framework of the low carbon city in China in the context of urbanization.

low-carbon cities in developed countries. The carbon-related regulations can improve emission reduction awareness and behaviors of policymakers and other related stakeholders [64] (Figure 5).

\section{Recommendations}

- Governments should make an assessment index system and incentive mechanisms which will encourage low-carbon production to provide low-carbon products to the market.

- The research centers need to focus on low-carbon technologies for providing technological support for the development of low-carbon cities in China.

- Awareness building program should be taken by the concerned authority on the importance of low-carbon consumption and low-carbon lifestyles.

- Local feasibility should be considered for designing, planning and implementing Low-carbon policy, practices and technology development for sustainable low carbon city development in the context of the new type of urbanization.

- The targets of government for low-carbon city development are not enough understanding to different stakeholders. So necessary steps should be taken by the concerned authority for implementing real works instead of just showing the achievements of local officials. Moreover, medium-sized or small cities should be taken into consideration for gross achievement in low carbon city development over the country. Additionally, building construction should be considered for low carbon city development irrespective of large, medium or small cities. 
- Governments should be taken the initiative to design proper rules and regulations for providing legal insurance for the development of low carbon industries, raising environmental awareness among people for promoting low-carbon practices, measuring and assessing emission reduction achievements, encouraging enterprises for focusing on innovative low-carbon technologies, improving industrial structures and energy structures.

\section{Conclusion}

The traditional urbanization pattern in China is a challenge for maintaining low carbon because of its relation to industrial development. Since industrial development is basically based on energy production, consumption, and trade. Low carbon city development in the process of the new type of urbanization is an academic debating matter in the researcher community particularly on developing an appropriate strategy, policy, technology, and action. This study reveals that most of the large cities are already under the pilot projects of low carbon city development. Some major indicators of low carbon city like economic growth, energy using pattern, social and lifestyle factor, carbon and environment, urban mobilization, solid waste management, and water management are related to urbanization. It also finds out some constraints like the traditional pattern of urbanization, the traditional pattern of industrial development, huge pressure on energy consumption, unawareness of the people about GHG emission, unavailability of low carbon technology, unequal emphasis on medium and small cities, and lack of proper assessment system. This study suggests that a standard assessment indicator system should be introduced by the government to control, monitor and stimulate people to use low carbon technology. It further suggests that rules and regulations, awareness building, local-oriented technology and practices, and stimulating participation of all stakeholders in the policy-making process should be maintained by the government for sustainable low carbon city in China. Further research should be done to address the performance of China's low-carbon city pilot projects and determining the role of government agencies for the development of low-carbon cities in China.

\section{References}

[1] Liu, W. and Qin, B. (2016) Low-Carbon City Initiatives in China: A Review from the Policy Paradigm Perspective. Cities, 51, 131-138. https://doi.org/10.1016/j.cities.2015.11.010

[2] Yu, L. (2014) Low Carbon Eco-City: New Approach for Chinese Urbanization. Habitat International, 44, 102-110. https://doi.org/10.1016/j.habitatint.2014.05.004

[3] Gouldson, A., Colenbrander, S., Sudmant, A., Papargyropoulou, E., Kerr, N., McAnulla, F. and Hall, S. (2016) Cities and Climate Change Mitigation: Economic Opportunities and Governance Challenges in Asia. Cities, 54, 11-19. https://doi.org/10.1016/j.cities.2015.10.010

[4] Kedia, S. (2016) Approaches to Low Carbon Development in China and India. Advances in Climate Change Research, 7, 213-221. 
https://doi.org/10.1016/j.accre.2016.11.001

[5] Su, M.R., Chen, B., Xing, T., Chen, C. and Yang, Z.F. (2012) Development of Low-Carbon City in China: Where Will It Go? Procedia Environmental Sciences, 13, 1143-1148. https://doi.org/10.1016/j.proenv.2012.01.107

[6] Dhakal, S. and Ruth, M. (2017) Creating Low Carbon Cities. Creating Low Carbon Cities, Springer International Publishing, Newyork, 208. https://doi.org/10.1007/978-3-319-49730-3

[7] Tan, S., Yang, J., Yan, J., Lee, C., Hashim, H. and Chen, B. (2017) A Holistic Low Carbon City Indicator Framework for Sustainable Development. Applied Energy, 185, 1919-1930. https://doi.org/10.1016/j.apenergy.2016.03.041

[8] Leimer, H.P. (2015) Low Carbon Economy in the Cities of China-Possibilities to Estimate the Potential os CO2-Emissions. Energy Procedia, 78, 2250-2255. https://doi.org/10.1016/j.egypro.2015.11.351

[9] Sarker, M.N.I. (2017a) An Introduction to Agricultural Anthropology : Pathway to Sustainable Agriculture. Journal of Sociology and Anthropology, 1, 47-52.

[10] Sarker, M.N.I. and Jie, Z. (2017) Social Security for Vulnerable Groups in Bangladesh on Government Perspective: Contribution of Research Leader. Journal of Public Policy and Administration, 1, 1-9.

[11] Liu, X. and Liu, J. (2016) Measurement of Low Carbon Economy Efficiency with a Three-Stage Data Envelopment Analysis: A Comparison of the Largest Twenty $\mathrm{CO}_{2}$ Emitting Countries. International Journal of Environmental Research and Public Health, 13, 1116. https://doi.org/10.3390/ijerph13111116

[12] Wang, C., Engels, A. and Wang, Z. (2017) Overview of Research on China's Transition to Low-Carbon Development: The Role of Cities, Technologies, Industries and the Energy System. Renewable and Sustainable Energy Reviews, 81, 1350-1364.

[13] Dong, L., Fujita, T., Zhang, H., Dai, M., Fujii, M., Ohnishi, S., Liu, Z., et al. (2013) Promoting Low-Carbon City through Industrial Symbiosis: A Case in China by Applying HPIMO Model. Energy Policy, 61, 864-873.

https://doi.org/10.1016/j.enpol.2013.06.084

[14] UN Habitat (2011) Global Report on Human Settlements 2011 "Cities and Climate Change".

[15] Fu, Y. and Zhang, X. (2017) Planning for Sustainable Cities? A Comparative Content Analysis of the Master Plans of Eco, Low-Carbon and Conventional New Towns in China. Habitat International, 63, 55-66. https://doi.org/10.1016/j.habitatint.2017.03.008

[16] Liu, J. and Deng, X. (2011) Impacts and Mitigation of Climate Change on Chinese Cities. Current Opinion in Environmental Sustainability, 3, 188-192. https://doi.org/10.1016/j.cosust.2010.12.010

[17] Wang, Z., Yin, F., Zhang, Y. and Zhang, X. (2012) An Empirical Research on the Influencing Factors of Regional $\mathrm{CO}_{2}$ Emissions: Evidence from Beijing City, China. Applied Energy, 100, 277-284. https://doi.org/10.1016/j.apenergy.2012.05.038

[18] Zhang, L., Li, Q. and Zhou, J. (2017) Critical Factors of Low-Carbon Building Development in China's Urban Area. Journal of Cleaner Production, 142, 3075-3082. https://doi.org/10.1016/j.jclepro.2016.10.160

[19] Cai, B., Geng, Y., Yang, W., Yan, P., Chen, Q., Li, D. and Cao, L. (2017) How Scholars and the Public Perceive a "Low Carbon City" in China. Journal of Cleaner Production, 149, 502-510. https://doi.org/10.1016/j.jclepro.2017.02.122

[20] Chen, Q., Cai, B., Dhakal, S., Pei, S., Liu, C., Shi, X. and Hu, F. (2017) $\mathrm{CO}_{2}$ Emission 
Data for Chinese Cities. Resources, Conservation and Recycling, 126, 198-208. https://doi.org/10.1016/j.resconrec.2017.07.011

[21] Adenle, A.A., Manning, D.T. and Arbiol, J. (2017) Mitigating Climate Change in Africa: Barriers to Financing Low-Carbon Development. World Development, 100, 123-132. https://doi.org/10.1016/j.worlddev.2017.07.033

[22] Liu, T., Wang, Y., Song, Q. and Qi, Y. (2017) Low-Carbon Governance in China-Case Study of Low Carbon Industry Park Pilot. Journal of Cleaner Production, 174, 837-846. https://doi.org/10.1016/j.jclepro.2017.10.339

[23] Lo, K. (2015) How Authoritarian Is the Environmental Governance of China? Environmental Science \& Policy, 54, 152-159. https://doi.org/10.1016/j.envsci.2015.06.001

[24] Lo, K. (2014) China's Low-Carbon City Initiatives: The Implementation Gap and the Limits of the Target Responsibility System. Habitat International, 42, 236-244. https://doi.org/10.1016/j.habitatint.2014.01.007

[25] Han, F., Xie, R., Lu, Y., Fang, J. and Liu, Y. (2018) The Effects of Urban Agglomeration Economies on Carbon Emissions: Evidence from Chinese Cities. Journal of Cleaner Production, 172, 1096-1110. https://doi.org/10.1016/j.jclepro.2017.09.273

[26] Yang, D., Liu, B., Ma, W., Guo, Q., Li, F. and Yang, D. (2017) Sectoral Energy-Carbon Nexus and Low-Carbon Policy Alternatives: A Case Study of Ningbo, China. Journal of Cleaner Production, 156, 480-490.

https://doi.org/10.1016/j.jclepro.2017.04.068

[27] Wang, X. and Chi, C. (2016) Global City Indicators: Towards a Holistic View of Low Carbon City Dimensions. Energy Procedia, 88, 168-175. https://doi.org/10.1016/j.egypro.2016.06.042

[28] Guo, R., Zhao, Y., Shi, Y., Li, F., Hu, J. and Yang, H. (2017) Low Carbon Development and Local Sustainability from a Carbon Balance Perspective. Resources, Conservation and Recycling, 122, 270-279. https://doi.org/10.1016/j.resconrec.2017.02.019

[29] Ma, X., Wang, Y. and Wang, C. (2017) Low-Carbon Development of China's Thermal Power Industry Based on an International Comparison: Review, Analysis and Forecast. Renewable and Sustainable Energy Reviews, 80, 942-970. https://doi.org/10.1016/j.rser.2017.05.102

[30] Cheshmehzangi, A., Xie, L. and Tan-mullins, M. (2017) The Role of International Actors in Low-Carbon Transitions of Shenzhen's International Low Carbon City in China. Cities, 74, 64-74.

[31] He, J.K. (2016) Global Low-Carbon Transition and China's Response Strategies. Advances in Climate Change Research, 7, 204-212. https://doi.org/10.1016/j.accre.2016.06.007

[32] Lv, J. and Qin, S. (2016) On Low-Carbon Technology. Low Carbon Economy, 7, 107-115. https://doi.org/10.4236/lce.2016.73010

[33] Yuan, Y. (2016) The Development Status, Problems and Countermeasures of China's Carbon Financial Market. Low Carbon Economy, 7, 62-69. https://doi.org/10.4236/lce.2016.71007

[34] Liang, M., Wang, Y. and Wang, G. (2014) China's Low-Carbon-City Development with ETS: Forecast on the Energy Consumption and Carbon Emission of Chongqing. Energy Procedia, 61, 2596-2599. https://doi.org/10.1016/j.egypro.2014.12.256

[35] Su, M., Zheng, Y., Yin, X., Zhang, M., Wei, X., Chang, X. and Qin, Y. (2016) Practice of Low-Carbon City in China: The Status Quo and Prospect. Energy Procedia, 
88, 44-51. https://doi.org/10.1016/j.egypro.2016.06.014

[36] Yang, L. and Li, Y. (2013) Low-Carbon City in China. Sustainable Cities and Society, 9, 62-66. https://doi.org/10.1016/j.scs.2013.03.001

[37] Zhou, Z., Liu, C., Zeng, X., Jiang, Y. and Liu, W. (2018) Carbon Emission Performance Evaluation and Allocation in Chinese Cities. Journal of Cleaner Production, 172, 1254-1272. https://doi.org/10.1016/j.jclepro.2017.10.208

[38] Zhou, N., He, G., Williams, C. and Fridley, D. (2015) ELITE Cities: A Low-Carbon Eco-City Evaluation Tool for China. Ecological Indicators, 48, 448-456. https://doi.org/10.1016/j.ecolind.2014.09.018

[39] Cheng, J., Zeng, G. and Fang, T. (2012) The Origin and Connotation of Low Carbon City: A Conceptual Framework. Proceedings of the 2012 th International Joint Conference on Computational Sciences and Optimization, Harbin, 23-26 June 2012, 706-709. https://doi.org/10.1109/CSO.2012.162

[40] Hu, B., Luo, J., Chen, C. and Li, B. (2015) Evaluating Low-Carbon City Development in China: Study of Five Low-Carbon Cities in China. 315-337.

[41] Feng, S., Huang, W., Wang, J., Wang, M. and Zha, J. (2015) Low-Carbon City and New-Type Urbanization: Proceedings of Chinese Low-Carbon City Development International Conference. Environmental Science and Engineering (Subseries. Environmental Science), 148, 273-284.

[42] Zhang, Z. (2016) Policies and Measures to Transform China into a Low-Carbon Economy. In: Song, L., Garnaut, R., Fang, C. and Johnston, L., Eds., China’s New Sources of Economic Growth, ANU Press, Canberra, 397-418. https://doi.org/10.22459/CNSEG.07.2016.17

[43] Riviere, P., Verges, M., Dimou, M. and Garde, F. (2013) Sustainable Cities in Tropical Climates: Presentation of the "Beausejour" Case Study in Reunion Island. WIT Transactions on Ecology and the Environment, 1, 641-650. https://doi.org/10.2495/SC130541

[44] Liu, S., Zhang, P., Wang, Z., Liu, W. and Tan, J. (2016) Measuring the Sustainable Urbanization Potential of Cities in Northeast China. Journal of Geographical Sciences, 26, 549-567. https://doi.org/10.1007/s11442-016-1285-0

[45] Suzuki, H., Dastur, A., Moffatt, S., Yabuki, N. and Maruyama, H. (2010) Eco2 Cities Ecological Cities as Economic Cities. The World Bank. https://doi.org/10.1596/978-0-8213-8046-8

[46] World Bank (2015) New Country Classifications Data. http://data.worldbank.org/news/new-country-classifications-2015

[47] UNESCAP (2012) Fact Sheet on Low Carbon Green Growth Roadmap for Asia and the Pacific. http://www.unescap.org/sites/default/files/Full-report.pdf

[48] Sarker, M.N.I. (2017) Smart City for Smart Citizen: Dimensions, Challenges and Opportunities for Developing Country. 5th Smart Cities Conference, Bucharest, 7 December 2017, 38.

[49] Adelaide City Council (2015) Carbon Neutral Adelaide A Shared Vision for the World's First Carbon Neutral City.

[50] Urban World (2009) Abu Dhabi to Build the World's First Zero Carbon City. Urban World, 66-70.

[51] Hannallah, G.M. and Faragallah, R.N. (2009) Zero-Carbon Cities as a New Realization of Sustainable Cities. In: Renewable Energy, Paper's No. BUE-FISC-124, 1-14.

[52] Wang, J. and He, D. (2015) Sustainable Urban Development in China: Challenges and Achievements. Mitigation and Adaptation Strategies for Global Change, 20, 
665-682. https://doi.org/10.1007/s11027-015-9644-1

[53] EIU (2012) The Green City Index.

http://aiph.org/wp-content/uploads/2015/04/Green\%20City\%20-\%20Guidelines.pdf

[54] Astiaso Garcia, D. (2017) Green Areas Management and Bioengineering Techniques for Improving Urban Ecological Sustainability. Sustainable Cities and Society, 30, 108-117. https://doi.org/10.1016/j.scs.2017.01.008

[55] WHO (2014) Ambient Air Quality and Health. Media Centre, WHO.

[56] Hoornweg, D. and Bhada, P. (2012) What a Waste. A Global Review of Solid Waste Management. Urban Development Series Knowledge Papers, 281, 44.

[57] Shen, L., Wu, Y., Lou, Y., Zeng, D., Shuai, C. and Song, X. (2018) What Drives the Carbon Emission in the Chinese Cities?-A Case of Pilot Low Carbon City of Beijing. Journal of Cleaner Production, 174, 343-354. https://doi.org/10.1016/j.jclepro.2017.10.333

[58] Baeumler, A., Ijjasz-Vasquez, E. and Mehndiratta, S. (2012) Sustainable Low-Carbon City Development in China.

[59] Li, Y., Lia, Y., Zhang, H., Liu, Y., Xu, W. and Zhu, X. (2011) Canadian Experience in Low Carbon Eco-City Development and the Implications for China. Energy Procedia, 5, 1791-1795. https://doi.org/10.1016/j.egypro.2011.03.305

[60] Addanki, S.C. and Venkataraman, H. (2017) Greening the Economy: A Review of Urban Sustainability Measures for Developing New Cities. Sustainable Cities and Society, 32, 1-8. https://doi.org/10.1016/j.scs.2017.03.009

[61] Feng, S., Huang, W., Wang, J., Wang, M. and Zha, J. (2015) Low-Carbon City and New-Type Urbanization: Proceedings of Chinese Low-Carbon City Development International Conference. Environmental Science and Engineering, 148, 273-284. https://doi.org/10.1007/978-3-662-45969-0

[62] Cao, S. and Li, C. (2011) The Exploration of Concepts and Methods for Low-Carbon Eco-City Planning. Procedia Environmental Sciences, 5, 199-207. https://doi.org/10.1016/j.proenv.2011.03.067

[63] Li, Q., Wei, Y.N. and Dong, Y. (2016) Coupling Analysis of China's Urbanization and Carbon Emissions: Example from Hubei Province. Natural Hazards, 81, 1333-1348. https://doi.org/10.1007/s11069-015-2135-6

[64] Huang, W., Wang, M., Wang, J., Gao, K., Chen, S.L. and Editors, L. (2016) China Low-Carbon Healthy City, Technology Assessment and Practice. Springer-Verlag GmbH, Berlin Heidelberg. https://doi.org/10.1007/978-3-662-49071-6 